\title{
Characterization of the hrpF Pathogenicity Peninsula of Xanthomonas oryzae pv. oryzae
}

\author{
Akiko Sugio, Bing Yang, and Frank F. White \\ Department of Plant Pathology, Throckmorton Hall, Kansas State University, Manhattan 66506-5502, U.S.A.
}

Submitted 10 December 2004. Accepted 14 February 2005.

\begin{abstract}
The hrp gene cluster of Xanthomonas spp. contains genes for the assembly and function of a type III secretion system (TTSS). The $h r p F$ genes reside in a region between $h p a B$ and the right end of the hrp cluster. The region of the hrpF gene of Xanthomonas oryzae pv. oryzae is bounded by two IS elements and also contains a homolog of hpaF of $X$. campestris pv. vesicatoria and two newly identified genes, hpa3 and hpa4. A comparison of the hrp gene clusters of different species of Xanthomonas revealed that the $h r p F$ region is a constant yet more variable peninsula of the $h r p$ pathogenicity island. Mutations in hpaF, hpa3, and hpa4 had no effect on virulence, whereas $h r p F$ mutants were severely reduced in virulence on susceptible rice cultivars. The hrpF genes from $X$. campestris pv. vesicatoria, $X$. campestris pv. campestris, and $X$. axonopodis pv. citri each were capable of restoring virulence to the $h r p F$ mutant of $X$. oryzae pv. oryzae. Correspondingly, none of the Xanthomonas pathovars with $h r p F$ from $X$. oryzae pv. oryzae elicited a hypersensitive reaction in their respective hosts. Therefore, no evidence was found for $h r p F$ as a host-specialization factor. In contrast to the loss of $B s 3$-dependent reactions by $h r p F$ mutants of $X$. campestris pv. vesicatoria, hrpF mutants of $X$. oryzae pv. oryzae with either avrXa10 or $a v r X a 7$ elicited hypersensitive reactions in rice cultivars with the corresponding $R$ genes. A double hrpFxoo-hpal mutant also elicited an $\mathrm{Xa10}$-dependent resistance reaction. Thus, loss of hrpF, hpal, or both may reduce delivery or effectiveness of type III effectors. However, the mutations did not completely prevent the delivery of effectors from $X$. oryzae pv. oryzae into the host cells.
\end{abstract}

Many pathogenic species of gram-negative bacteria have type III secretion systems (TTSS) that are required for disease in their specific hosts. Hypersensitive reaction and pathogenicity (hrp) proteins are the main components of the TTSS in plantpathogenic bacteria (Lindgren 1986) and are required for delivery of the secreted substrate proteins, which consist of virulence effectors and the so-called avirulence (Avr) proteins. Many TTSS effectors and Avr proteins enter the host cells via an unknown mechanism after delivery by the TTSS pathway (Buttner and Bonas 2002a). In the case of Avr proteins, internalization triggers a hypersensitive reaction (HR) in plants carrying corresponding resistance $(R)$ genes. The HR is a localized plant cell death and part of the plant defense mechanism for prevention of further pathogen ingress. A set of nine hrp genes, which encode structural components of the TTSS, are well conserved between gram-negative plant and animal patho-

Corresponding author: Frank F. White; Telephone: (785) 532-6176; Fax: (785) 532-5692; E-mail fwhite@ ksu.edu gens and are called $h r p$-conserved $(h r c)$ genes. The hrp-associated $(h p a)$ genes represent another set of genes from Xanthomonas spp. (Buttner and Bonas 2002a). The hpa genes may contribute to virulence, but strains with mutations in hpa genes generally do not exhibit the severe phenotypic changes in disease symptoms compared with hrp gene mutations. The hrp, $h r c$, and hpa genes are clustered in a chromosomal region known as the hrp gene cluster. The hrp gene clusters from the various species also have properties of pathogenicity islands, which are genes flanked by mobile genetic elements, tRNArelated sequences, or atypical GC composition for the particular genome (Alfano et al. 2000; Hacker and Kaper 2000). Pathogenicity island structures are construed as evidence of genetic exchange among bacteria and genetic rearrangements.

The hrp gene clusters of Xanthomonas axonopodis pv. glycine (Kim et al. 2003), X. campestris pv. vesicatoria, X. campestris pv. campestris, and $X$. axonopodis pv. citri (da Silva et al. 2002) have been sequenced, and the genetic organization of the left and right borders of the hrp gene clusters, though highly similar, have variations in terms of overall structure and gene content between the species. Whether any of the variations contribute to host specialization is unknown. One of the variable loci present in the right side of hrp gene cluster of Xanthomonas spp. is $h r p F$. X. axonopodis pv. glycine and X. axonopodis pv. citri both contain $h r p F$ and a second locus known as hpaF, whereas $X$. campestris pv. vesicatoria has $h r p F, h p a F$, and a third gene named $h p a G$ (Noel et al. 2002). Both $h p a F x c v$ and $h p a G x c v$ have high similarity with different portions of the hpaF genes of other species. X. campestris pv. campestris has $h r p F x c c$ in the opposite orientation relative to other hrp gene clusters and does not have an $h p a F$ homolog at the right border. Instead, X. campestris pv. campestris has a homolog of hrpW, which originally was identified in Erwinia and Pseudomonas spp. (Charkowski et al. 1998; Kim and Beer 1998). hpaF encodes a leucine-rich repeat protein. However, no function for $h p a F$ had been ascribed in virulence or avirulence until recently, when mutations in hpaF of $X$. axonopodis pv. glycine were reported to contribute to virulence (Kim et al. 2003). In addition to genes in the other Xanthomonas pathogens, the $h r p F$ gene product $(\mathrm{HrpF})$ shares amino acid sequence similarity with NolX from Sinorhizobium fredii USDA257 (Krishnan 2002), which is secreted during the early stage of nitrogen-fixing nodule development and required for efficient nodule formation (Bellato et al. 1997; Krishnan 2002; Meinhardt et al. 1993), and two predicted proteins, PopF1 and PopF2, from Ralstonia solanacearum (Salanoubat et al. 2002).

The hrpF gene from $X$. campestris pv. vesicatoria has been studied in more detail (Buttner et al. 2002). HrpFxcv is secreted via the TTSS (Rossier et al. 2000) and has two N-terminal imperfect direct repeats and a C-terminal hydrophobic segment (Huguet and Bonas 1997). The protein also has lipid- 
binding activity and the ability to form ion-conducting pores in artificial lipid bilayers (Buttner et al. 2002). HrpFxcv was found not to be required for the secretion of TTSS substrate proteins but was required for the elicitation of a $B s 3$-dependent HR in pepper by AvrBs3 (Rossier et al. 2000). The behavior of $\mathrm{HrpF}$ provides evidence that the protein may be inserted in plant cell membrane and required for the type III effector proteins to enter the host cells (Buttner et al. 2002). Therefore, as a translocon, HrpF would contact the plant cell membrane directly and possibly be subjected to the plant surveillance mechanisms. As an essential and conserved component of the TTSS, HrpF and similar TTSS components represent attractive targets for genetic resistance strategies that may provide broad and durable resistance to some bacterial diseases. This study reports the characterization of hrpFxoo and the surrounding region from $X$. oryzae pv. oryzae and the results of the exchange of the $h r p F$ alleles from different species.

\section{RESULTS}

\section{The $h r p F$ region}

of $X$. oryzae pv. oryzae is bounded by IS elements.

Cosmid pAS49 was retrieved from a genomic library of $X$. oryzae pv. oryzae strain $\mathrm{PXO} 99^{\mathrm{A}}$ by hybridization using an $h r p F$ fragment probe designed from the related published sequence, and a 12.9-kb region was sequenced, revealing the organization of the right end of the hrp gene cluster (Fig. 1). The region included nine open reading frames (ORFs), including an $X$. campestris pv. vesicatoria hrpF homolog ( $r$ rpFxoo) and two insertion elements. A second ORF, with similarity to both the $h p a F$ and $h p a G$ genes of $X$. campestris pv. vesicatoria and named hpaFxoo, was located immediately downstream of hrpFxoo. The $5.1 \mathrm{~kb}$ of DNA between hrpFxoo and a homolog of the $h p a B$ of $X$. campestris pv. vesicatoria included two ORFs, which were designated as hpa3 and hpa4, and a portion of sequence related to the ISXo8 transposase. An insertion element was located immediately to the right of the conserved $h p a B$ gene (Fig. 1, IS1). BLAST analysis of IS1 revealed 2 related copies in the region of the xanthomonadin biosynthesis export pathway in strain BXO1 of X. oryzae pv. oryzae (Goel et al. 2002), 18 copies in $X$. axonopodis pv. citri 306, and 71 copies in X. campestris pv. campestris ATCC33913 (da Silva et al. 2002), although the related copies were not associated with the respective hrp gene clusters. A second insertion element was found immediately downstream of hpaF (Fig. 1, IS2). The region downstream of IS2 encoded three putative ORFs with highest similarity and colinear to three non-hrpassociated or linked hypothetical proteins from $X$. axonopodis pv. citri (ORFs XAC3981, XAC3982, and XAC3983 in accession number AE012047). The IS2 element was designated the right end of the $h r p F$ region and the right end of $h r p$ gene cluster of strain PXO99A.

The regions of $h r p F$ from different species of Xanthomonas were aligned and compared from the $h p a B$ locus to the right end of the respective hrp gene clusters. $X$. axonopodis pv. citri and $X$. axonopodis pv. glycines are virtually colinear throughout the region, whereas the $X$. campestris pv. vesicatoria region is very similar to the corresponding region of $\mathrm{PXO} 99^{\mathrm{A}}$ and also ends in a tRNA sequence (Fig. 1). X. campestris pv. vesicatoria encoded sequences similar to hpa3 and hpa4, but the sequence related to hpa 3 had a stop codon in the middle of the gene. $X$. axonopodis pv. glycines encoded sequences related to $X$. oryzae pv. oryzae hpa3, and only partial similarity with hpa4. Upstream of the hpa3-related sequences is an imperfect plant-inducible promoter (PIP) box (TTCGT...15nt... TTCGC). The $X$. campestris pv. campestris sequence was not related to hpa 3 but encoded a sequence related to a $\mathrm{C}$-terminal coding portion of hpa4 that was designated previously as XCC1218 (da Silva et al. 2002). Of five sequences, only $X$. oryzae pv. oryzae carried intact hpa3 and hpa4. Therefore, the $h r p F$ region of the respective hrp clusters of the different Xanthomonas species forms a peninsula of genetic variability connected to the main hrp pathogenicity island.

hrpF mutants have reduced virulence, whereas mutations in hpa3, hpa4, and hpaF did not affect the virulence.

The hrpF locus and surrounding region of $X$. oryzae pv. oryzae has not been characterized genetically; therefore, mutations in the individual ORFs were created. The $h r p F$ mutant ASX41 was generated by an integration of a plasmid which

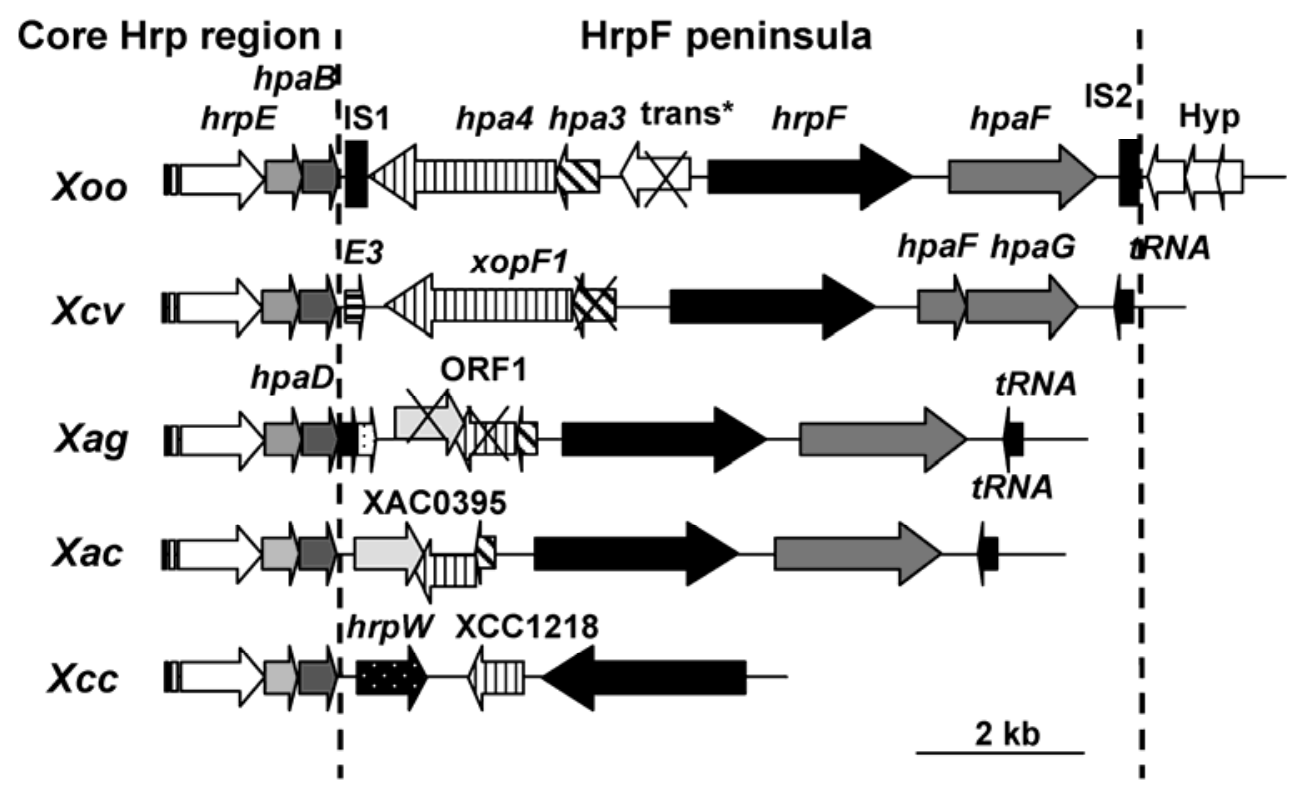

Fig. 1. Comparison of the $h r p F$ peninsulas of five Xanthomonas spp. Dashed vertical lines indicate the region of the $h r p F$ peninsula. The following sequences were used: AY536514 (Xanthomonas oryzae pv. oryzae; Xoo), AF056246 (X. campestris pv. vesicatoria; Xcv), AF499777 (X. axonopodis pv. glycines; Xag), AE011665 (X. axonopodis pv. citri; Xac), and AE012221 (X. campestris pv. campestris; Xcc). Arrows with crosses indicate open reading frames (ORFs) that are either disrupted or carrying a frame shift mutation. 
contains a partial $h r p F$ sequence by single homologous recombination. Virulence of ASX41 was determined by measuring lesion lengths and bacterial numbers in inoculated leaves, and the results were compared with similar measurements for the parental strain PXO99 ${ }^{\mathrm{A}}$ and the $h r p C 1$ mutant PXO99 ${ }^{\mathrm{A}} \mathrm{ME7}$. PXO99 ${ }^{\mathrm{A}} \mathrm{ME} 7$ has a defective TTSS and is essentially nonpathogenic. ASX41 showed both reduced lesion lengths (Fig. 2A) and bacterial growth (Fig. 2B) in rice leaves compared with the parental strain PXO99 ${ }^{\mathrm{A}}$ but caused longer lesions and had more growth than the nonpathogenic strain PXO99 ${ }^{\mathrm{A}} \mathrm{ME7}$. The difference between the virulence of ASX41 and PXO99 ${ }^{\mathrm{A}} \mathrm{ME7}$ indicated that the $h r p F$ mutant still was competent for secretion of virulence effectors into the plant cells. When the complete $h r p F$ gene in pAS65 was introduced into $h r p F$ mutant ASX41, the mutant was restored to full virulence (Fig. 2A). To rule out that the residual virulence of ASX41 was due to a low level of reversion during growth in the plant, a second $h r p F$ mutant strain, ASX85, was generated by double recombination of a transposon into the hrpF locus. ASX85 showed the same loss of virulence as the single recombinant strain ASX41 and was more virulent than PXO99 ${ }^{\mathrm{A}}$ ME7 (data not shown). The hpa3, hpa4, and hpaF also were inactivated individually by homologous recombination, and none of the respective mutants showed significant differences in lesion length compared with the parental strain $\mathrm{PXO}^{\mathrm{A}}$ (data not shown).

\section{hrpF mutants are competent for race-specific reactions.}

Mutations in hrpF of $X$. campestris pv. vesicatoria prevented the elicitation of resistance in pepper plants containing the resistance gene $B s 3$ by bacteria harboring the avrBs3 avirulence gene (Rossier et al. 2000). Strains of $X$. oryzae pv. oryzae contain homologs to avrBs3, including the genes avrXa7 and $a v r X a 10$ (Hopkins et al. 1992). Experiments were performed to determine whether the hrpFxoo2 mutant was able to deliver AvrXa7 and AvrXa10 into plant cells based on an $R$ gene-specific HR. The plasmids pZWavrXa10 and pZWavrXa7 contain the avirulence genes avrXal0 and avrXa7, respectively, and strains of $X$. oryzae pv. oryzae con- taining the genes elicit resistance when inoculated on rice plants with either $X a 10$ or $X a 7$, respectively. When introduced into the $h r p F$ mutant ASX41, both resulting strains caused typical water-soaked symptoms on IR24 and an HR on the respective plants containing either Xa10 or Xa7 (Fig.3A; IRBB7, results not shown). However, the degree of the water soaking and HR were reduced compared with the wild-type responses. $P O X 22.3$ is a rice peroxidase gene that is induced specifically during the resistance reactions caused by PXO99 ${ }^{\mathrm{A}}$ harboring either $a v r X a 10$ or $a v r X a 7$, whereas TFIIA $\gamma 1$ is a rice gene that is specifically induced by $\mathrm{PXO} 99^{\mathrm{A}}$ in susceptible interactions. (Chittoor et al. 1997; unpublished results). Both genes are not induced by bacteria lacking a functional TTSS. However, $P O X 22.3$ was induced upon inoculation of plants with ASX41 harboring pZWavrXa10, and TFIIA $\gamma 1$ was induced by ASX41 (Fig. 3B and C). TFIIA $\gamma 1$ induction was reduced in the level of induction based on the intensity of the bands.

The results indicated that the $h r p F$ mutant of $X$. oryzae pv. oryzae retained at least a partial ability to translocate AvrXa10 and virulence effectors into plant cells. HrpF was reported to be required for $B s 3$-dependent resistance in pepper (Rossier et al. 2000); therefore, avrBs3 and avrBsl were introduced into PXO99 ${ }^{\mathrm{A}}$, which is not pathogenic and does not elicit a nonhost HR on pepper, and the $h r p F$ mutant ASX41, respectively. Each strain was inoculated on pepper plants $30 \mathrm{R}$ or $10 \mathrm{R}$ that carried either $B s 3$ or $B s 1$, respectively. Although $\mathrm{PXO} 99^{\mathrm{A}}$ harboring $a v r B s 3$ or $a v r B s 1$ induced the appropriate gene-specific resistance reactions on pepper plants with $30 \mathrm{R}$ or $10 \mathrm{R}$, respectively, ASX41 harboring $a v r B s 3$ or $a v r B s 1$ did not induce visible resistance reactions with either $a v r / R$ gene combination (data not shown).

Hpal is a harpin-like protein encoded by the hpal locus of $X$. oryzae pv. oryzae (Zhu et al. 2000). Harpin-like proteins also have been postulated to function as translocons in the TTSS and are known to form pores on lipid bilayers (Lee et al. 2001). Therefore, hpal was hypothesized to represent a second gene controlling the uptake of effectors by the plant cells and responsible for the residual virulence and elicitor activity of the $h r p F$ mutants. To investigate this hypothesis, an hpal hrpF
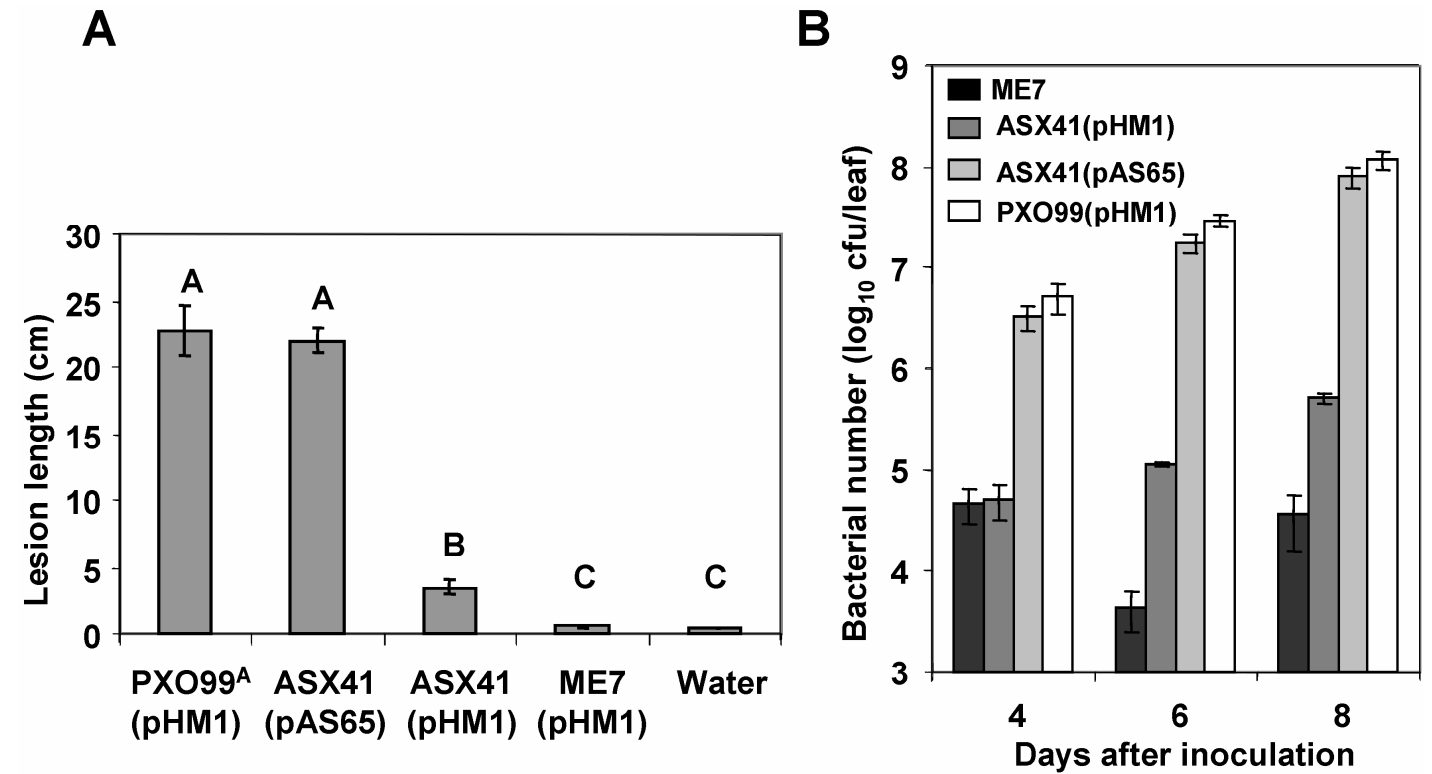

Fig. 2. $h r p F$ mutants are reduced in virulence but remain pathogenic. A, Lesion-length measurements of hrpF mutants. The third leaf of IR24 seedlings was inoculated individually with PXO99 (wild type) harboring pHM1 (empty plasmid), ASX41 ( $h r p F$ mutant) harboring pAS65 (hrpFxoo2), ASX41 harboring pHM1, ME7 ( $h r p C$ mutant) harboring pHM1, and water. The lesion lengths after 12 days are shown. B, Bacterial leaf populations of $h r p F$ mutants. The third leaf of 14-day-old IR24 seedlings were clip inoculated with PXO99 ${ }^{\mathrm{A}}$ (pHM1), ASX41 (pAS65), ASX41 (pHM1), and PXO99 ${ }^{\mathrm{A}}$ ME7 (pHM1), and a 20-cm portion of three leaves was harvested on the indicated days. Statistically different data groups $(P<0.05)$ are indicated by different letters. 
double mutant, ASX153, was generated along with a single hpal mutant, ASX155. The virulence of hrpF hpal double mutant ASX153 was weaker compared with the reactions of the hpal mutant ASX155, hrpF mutant ASX85, and wild-type strain PXO99 ${ }^{\mathrm{A}}$ and weakly virulent compared with the nonpathogenic hrpC mutant PXO99 ${ }^{\mathrm{A}} \mathrm{ME7}$ (Fig. 4). The plasmid pZWavrXal0 was introduced into hrpF hpal double mutant ASX153 and the transformant was inoculated on rice lines IR24 and IRBB10. Although weaker, ASX153 harboring pZWavrXa10 triggered an Xal0-dependent HR in IRBB10 (data not shown) and concomitantly elicited the induction of POX22.3 in IRBB10. PXO99 ${ }^{\mathrm{A}}$ ME7 with pZWavrXa10, in comparison, neither triggered an HR (data not shown) nor elicited the induction of POX22.3 above levels observed for the control infiltration with water (Fig. 5).

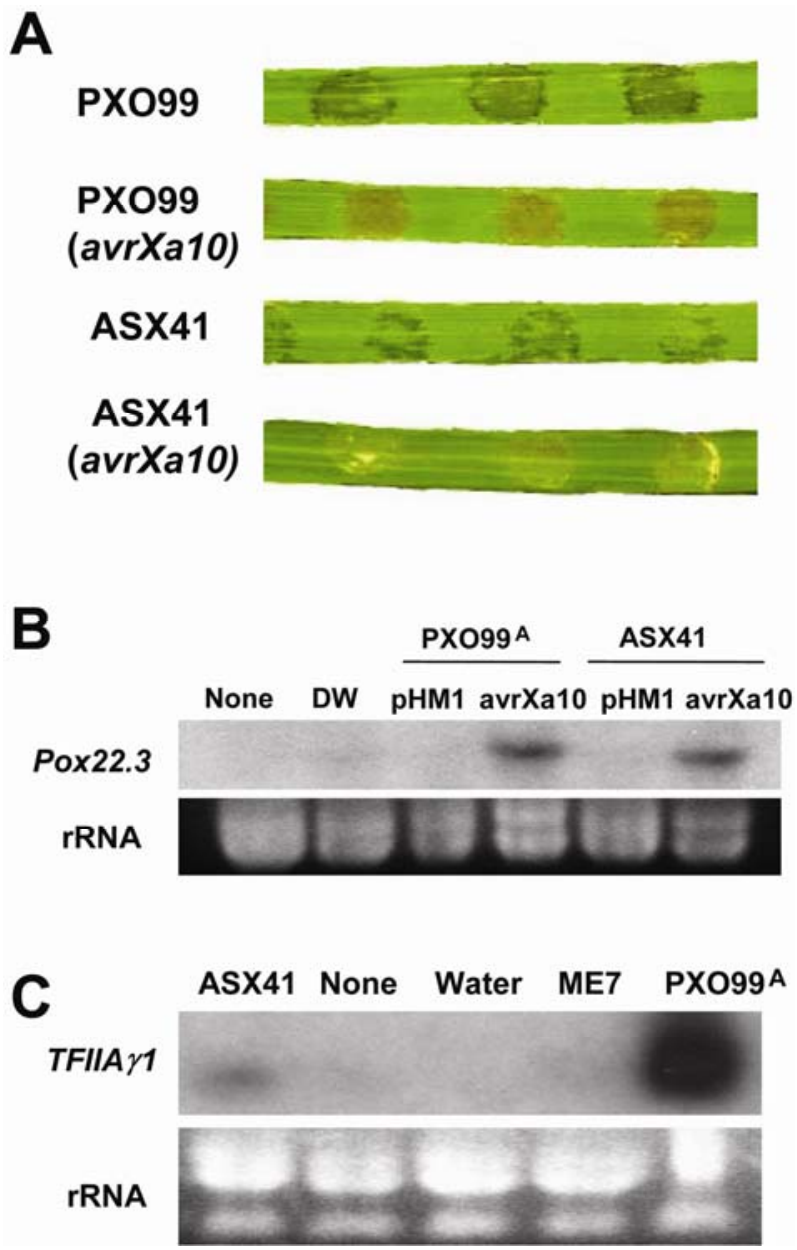

Fig. 3. $h r p F$ mutants are competent for $R$ gene-specific reactions. A, The second leaf of 14-day-old seedlings of IRBB10 was inoculated by needleless syringe with PXO99 ${ }^{\mathrm{A}}$ (pHM1), PXO99 ${ }^{\mathrm{A}}$ (pZWavrXa10), hrpFxoo mutant ASX41 (pHM1), and ASX41 (pZWavrXa10). Both PXO99 $^{\mathrm{A}}$ and ASX41 harboring pZWavrXa10 triggered a hypersensitive response (HR) on IRBB10, whereas both strains without avrXa10 caused water soaking on IRBB10. B, Total RNA was prepared from 14-day-old IRBB10 leaves $12 \mathrm{~h}$ after inoculated with either water, PXO99 ${ }^{\mathrm{A}}$ (pHM1),

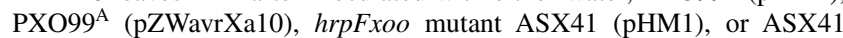
(pZWavrXa10). The RNA was fixed on a membrane and hybridized with a probe for POX22.3, which is induced during HR. ASX41 (pZWavrXa10) induced $P O X 22.3$. C, The second leaf of 14-day-old rice IR24 was inoculated with PXO99 ${ }^{\mathrm{A}}, \mathrm{ASX} 41, \mathrm{PXO} 99^{\mathrm{A}} \mathrm{ME} 7$ ( $h r p C$ mutant), and water. The leaves were harvested $24 \mathrm{~h}$ after inoculation and subjected to Northern analysis with a probe for TFIIA $\gamma 1$. PXO99 ${ }^{\mathrm{A}}$ induced TFIIA $\gamma 1$ fully, and $h r p F$ mutant ASX41 partially induced TFIIA $\gamma 1$, whereas $h r p C$ mutant PXO99 ${ }^{\mathrm{A}} \mathrm{ME7}$ did not induce TFIIA $\gamma 1$.
hrpF alleles complement loss of hrpFxoo.

The $h r p F$ alleles of the various species and pathovars of Xanthomonas have a greater degree of sequence divergence relative to the conserved core hrp genes. Overall HrpFxoo similarity with $\mathrm{HrpF}$ from $X$. campestris pv. vesicatoria is $94 \%, X$. axonopodis pv. glycine $84 \%, X$ axonopodis pv. citri $80 \%$, and $X$. campestris pv. campestris $59 \%$ at the protein level. The alleles, with the exception of HrpFxcc, have the two $\mathrm{N}$-terminal repeat sequences and two $\mathrm{C}$-terminal hydrophobic sequences which previously were identified in HrpFxcv (Huguet and Bonas 1997). HrpFxcc has three N-terminal repeat sequences. The differences may represent adaptations of the respective strains to the respective host plants. To examine this possibility, the genes from $X$. campestris pv. campestris, $X$. campestris pv. vesicatoria, and $X$. axonopodis pv. citri were cloned and tested for complementation of hrpFxoo of PXO99A ${ }^{A}$ Each gene was cloned with the original promoter and introduced into hrpFxoo mutant ASX41, and the transformants were inoculated on rice. None of the transformants triggered an HR on rice (data not shown), and all three $h r p F$ genes complemented the hrpFxoo 2 mutation as determined by measurement of lesion lengths on inoculated leaves (Fig. 6). Conversely, pAS65 containing hrpFxoo was introduced into $X$. campestris pv. campestris 33913, X. axonopodis pv. citri 306, and $X$. campestris pv. vesicatoria XV157, and the resulting strains were inoculated on their respective host plants. $X$. campestris pv. campestris 33913 and X. axonopodis pv. citri

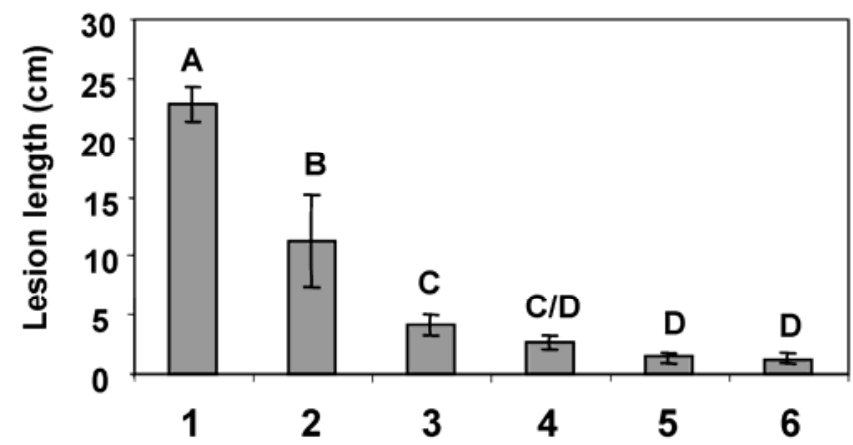

Fig. 4. hrpF hpal double mutant is weakly virulent. The third leaf of 14day-old rice plants of IR24 was inoculated with the following strains: 1 , PXO99 ${ }^{\text {A } ; ~ 2, ~ A S X 155 ~(h r p A ~ m u t a n t) ; ~ 3, ~ A S X 85 ~(h r p F ~ m u t a n t) ; ~ 4, ~ A S X 153 ~}$ ( $h r p F$ and $h r p A$ double mutant); 5, PXO99 $\mathrm{ME7}$ (hrpC mutant); and 6, water. The lesion lengths were measured each day after inoculation. The results after the 14th day are shown. Statistically different data groups $(P<$ 0.05 ) are indicated by different letters.

ME7 ASX153 PXO99A

Pox22.3

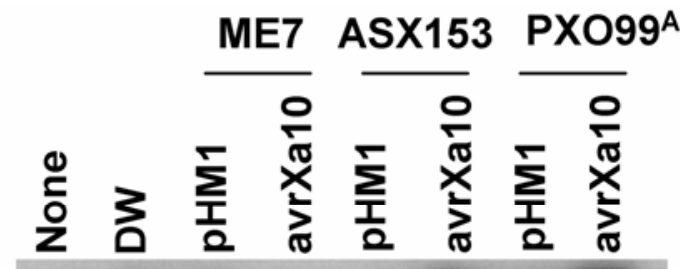

rRNA

Fig. 5. hrpF hpal double mutant is competent for $R$ gene-specific reactions. Total RNA was prepared from IRBB10 intact leaves or leaves densely inoculated with water, hrpC mutant PXO99 ${ }^{\mathrm{A}} \mathrm{ME7}$ (pHM1), PXO99 ${ }^{\mathrm{A}} \mathrm{ME7}$ (pZWavrXa10), hrpF hpaA double mutant ASX153 (pHM1), ASX153 (pZWavrXa10), wild-type PXO99 ${ }^{\mathrm{A}}$ (pHM1), or PXO99 ${ }^{\mathrm{A}}$ (pZWavrXa10) $12 \mathrm{~h}$ after inoculation and subjected to Northern analysis using a POX22.3specific probe. ASX153 harboring pZWavrXa10 induced POX22.3 weakly. 
306 were tested on cabbage and grapefruit, respectively. $X$. campestris pv. vesicatoria XV157 was tested on tomato and pepper. PXO99 ${ }^{\mathrm{A}}$ itself caused an $\mathrm{HR}$ on cabbage and tomato and did not show any phenotype on citrus. $X$. campestris pv. campestris $33913, X$. axonopodis pv. citri 306, and X. campestris pv. vesicatoria XV157 with pAS65 did not trigger HR on any of the respective host plants (data not shown).

\section{DISCUSSION}

The HrpF peninsula, which is defined here as the region of the $h r p$ pathogenicity island lying between $h p a B$ and the right end of the hrp gene cluster, is a region of relatively high nucleotide and gene variability within the hrp gene clusters of different Xanthomonas spp.. In X. oryzae pv. oryzae, the region is bounded by two IS elements and encompasses four ORFs and a degenerate coding region with similarity to a gene for transposase. The right end in $X$. oryzae pv. oryzae is defined by an insertion element, which occurs between the homolog of $h p a F$ and three ORFs that are colinear with a region of the $X$. axonopodis pv. citri genome. However, the three ORFs in $X$. axonopodis pv. citri are not linked to the hrp gene cluster, indicating that a rearrangement of the region occurred or that different insertion events of hrp clusters occurred in the two species.

The peninsula of $X$. oryzae pv. oryzae, as represented in PXO99 ${ }^{\mathrm{A}}$, has two novel complete ORFs, designated hpa3 and hpa4 that are only partially represented in the $h r p F$ peninsula of other species and pathovars. The ORFs appear to be organized within an operon and are preceded by a PIP motif located $121 \mathrm{bp}$ upstream of the putative operon. The genes also were expressed in an HrpX-dependent manner (A. Sugio and F. F. White, unpublished data). The organization of the genes and the small, acidic, and leucine-rich nature of the predicted protein for hpa 3 suggested that the hpa3 product may be a chaperone for the product of hpa4 for secretion by the type III system. However, these predictions remain to be verified by functional analyses. In any event, mutations in either ORF did not affect the virulence as measured by the lengths of lesion on plants. Recently, a genome-wide screening of TTSS effectors of $X$. campestris pv. vesicatoria identified a homolog of $\mathrm{Hpa} 4$ called XopF1, providing further evidence that $\mathrm{Hpa} 4$ represents a type III effector (Roden et al. 2004). Similar to the results with hpa4, mutants in the gene corresponding to XopF1 did not result in an appreciable loss of virulence by X. campestris pv. vesicatoria (Roden et al. 2004). The presence of intact hpa3 and hpa 4 in X. oryzae pv. oryzae and related but partial or degenerate sequences in the related pathogens provides clues that the $h r p F$ peninsula of $X$. oryzae pv. oryzae may reflect the founding hrp gene cluster of the common ancestor.

Mutations in $h r p F$ were the only mutations in the genes of the peninsula that affected the ability of the bacterium to cause disease. Previous evidence has shown that secretion of the protein occurs via the TTSS system, and alleles of HrpF have variations in their amino acid sequence similar to the substrate effectors. At the same time, $h r p F$ alleles are found in all of the species and pathovars of Xanthomonas that have been examined, and related genes are found in strains of $R$. solanacearum and several Rhizobium species. HrpF also is generally required for pathogenicity. Previous studies with $h r p F$ alleles of $X$. campestris pv. vesicatoria and $X$. axonopodis pv. glycines indicated that mutations in $h r p F$ resulted in strains that were nonpathogenic and unable to elicit race-specific HRs (Kim et al. 2003; Rossier et al. 2000). Mutants of $h r p F$ in $X$. oryzae pv. oryzae were not devoid of pathogenicity. The mutant strains displayed both a reduced ability to grow within the host and reduced ability to cause lesions. However, the mutants were more virulent compared with a mutant for the secretion apparatus.

The proposed $\mathrm{HrpF}$ function as a translocon and as a secreted protein places the protein at the plant-bacterium interface (Rossier et al. 2000). Like the effector proteins, HrpF possibly would be subject to the diversifying selective pressure to avoid detection from the plant defense mechanisms or to meet special structural requirements for function in different host species. Differences are found among the encoded proteins of the alleles. The most striking is the number of $\mathrm{N}$-terminal imperfect repeat sequences. HrpFxcc has three repeats, whereas proteins from other Xanthomonas strains have two repeat sequences. NolX from $S$. fredii has only one. A series of studies on HrpFxcv showed that one repeat was sufficient for $h r p F$ function in Xanthomonas spp., but hrpFxcv and nolX were not functionally interchangeable (Huguet and Bonas 1997). The results further indicated that the repeat in some manner stabilized the structure of HrpF (Buttner et al. 2002). No evidence for a role of $\mathrm{HrpF}$ in the adaptation of Xanthomonas spp. to the different

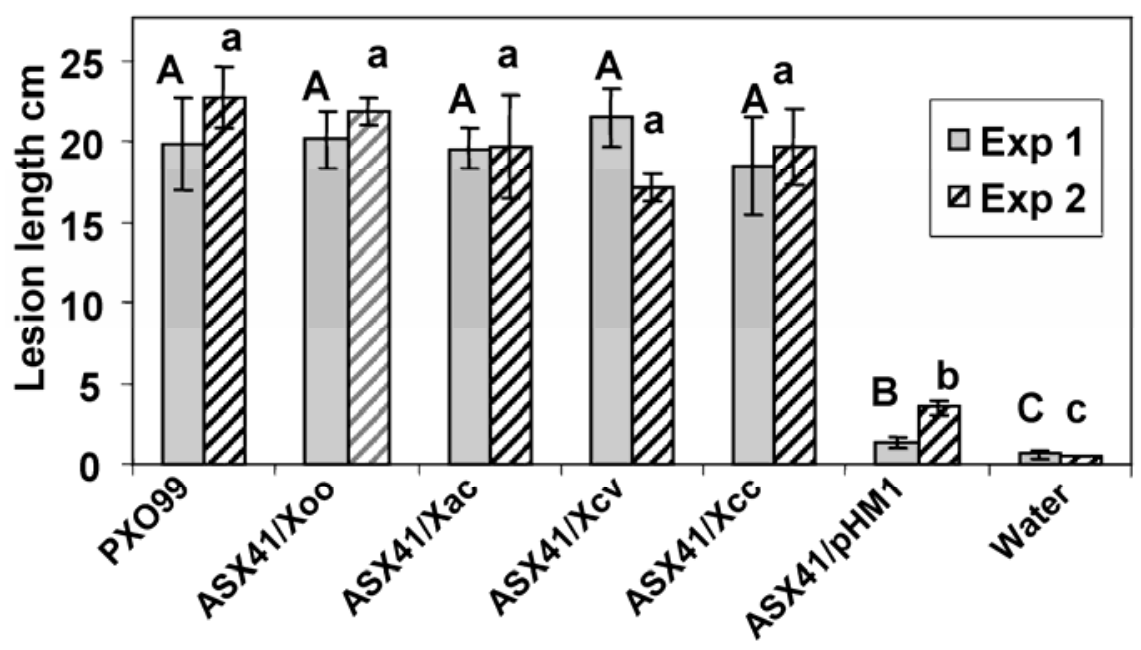

Fig. 6. Alleles of $h r p F$ from different Xanthomonas strains complement the mutation in hrpFxoo2. The third leaf of 21-day-old seedling of IR24 was inoculated with PXO99 (pHM1), hrpFxoo2 mutant ASX41 (pAS65:hrpFxoo2), ASX41 (pAS74:hrpFxac), ASX41 (pAS76:hrpFxcv), ASX41 (pAS109:hrpFxcc), ASX41 (pHM1), and water. The lesion lengths were measured each day after the inoculation. The results, which represent the mean of three leaves, after the 12th day are shown. Statistically different data groups $(P<0.05)$ are indicated by different letters. The graph shows the results of two experiments. 
host species was apparent from these studies. All of the homologous genes that were tested could complement the loss of hrpFxoo 2 to the extent revealed by lesion-length assays. Similarly, an analysis of the synonymous and nonsynonymous substitutions did not reveal whether the genes were subject to diversifying selection (data not shown). Therefore, the $h r p F$ alleles of Xanthomonas spp. were not critical host determinants in the pathogen-host combination used in this study or under the experimental conditions. The results do not eliminate the possibility that specific $h r p F$ alleles may function more efficiently in effector transfer in the respective hosts, which could have important ecological impacts on the persistence of the bacteria in the environment.

The mechanism of protein translocation across the host cell wall remains unclear. Gram-negative bacteria secrete virulence factors through the extracellular needle-like structure (pilus) into host cells. Plant-pathogenic bacteria have longer TTSS than animal-pathogenic bacteria, which may reflect the need to penetrate thick plant cell walls (Roine et al. 1997). Some evidence showed that pili of plant-pathogenic bacteria penetrate the wall (Brown et al. 2001). However, whether pili penetrate the cellular plasmalemma is subject to debate. The translocation of the effectors into the host cells may be mediated by a protein or protein complex called a translocon (Buttner and Bonas 2002b). In the case of the animal pathogen Yersinia, the protein LcrV forms channel-like pores in eukaryotic cell membranes by itself (Holmstrom et al. 2001), and YopB and YopD also are required for protein translocation. Both proteins were found to be inserted in liposomes (Neyt and Cornelis 1999). YopB and YopD are hypothesized to stabilize the pore formed by LcrV and constitute the translocon protein complex, and all three are required to form functional translocon complexes (Broms et al. 2003).

$\mathrm{HrpF}$, harpins, and harpin-like proteins have been proposed to function in facilitating effector transfer in plant-pathogenic bacteria. HrpFxcv formed pores in an artificial lipid bilayer. The protein also was required for race-specific reactions using the $a v r B s 3 / B s 3$ combination despite the fact that AvrBs3 was delivered to the extracellular milieu, suggesting an absolute requirement for $\mathrm{HrpF}$ in the delivery of effectors into the host cell (Rossier et al. 2000). In contrast to X. campestris pv. vesicatoria, hrpF mutants of $X$. oryzae pv. oryzae delivered AvrXa10 or AvrXa7, which require internalization for activity (Zhu et al. 1998), into rice cells on the basis of respective $R$ gene-specific resistance reactions and the specific induction of a gene for peroxidase. The mutants also were able to induce genes for peroxidase and TFIIA $\gamma 1$, which are rice genes induced in a TTSS-dependent manner. The residual virulence and avirulence activities could not be explained by reversion of the mutants. The results indicate that HrpF, although a possible facilitator of transport, is not absolutely required for the translocation of TTSS proteins into plant cells. A similar observation was observed for the $h r p K$ gene, which is a possible homolog of $\mathrm{HrpF}$ in Pseudomonas syringae pv. tomato. Mutations in $h r p K$, although reducing activity, did not eliminate virulence and the ability of the bacteria to elicit an $R$ gene-dependent HR (Petnicki-Ocwieja et al. 2005).

The results concerning Xal0-dependent elicitation by $h r p F$ mutants may be explained by several alternative hypotheses. First, additional pore-forming proteins in addition to $\mathrm{HrpF}$ may exist. Harpins also have been postulated to create pores in plant cell membranes (Lee et al. 2001). Hpa1 is the product of the hpal gene and a hairpin-like protein present in all species of Xanthomonas examined (Kim et al. 2003; Noel et al. 2002; Zhu et al. 2000). However, the double hpal hrpFxoo2 mutant still elicited Xa10-dependent resistance, indicating that Hpa1 and $\mathrm{HrpF}$ are not solely responsible for effector translocation.
A second possibility is that plant cells themselves have the ability to take up proteins delivered to the cell membrane by endocytosis (Horn et al. 1989). In the absence of HrpF (and Hpa1), AvrXa10 and some other virulence factors may be delivered to the plant membrane in quantities sufficient for uptake by the plant cells resulting in subsequent elicitation. A third explanation is that the TTSS needle-like structure may actually puncture some of the plant cells and secrete the effector proteins directly into the plant cells (Hoiczyk and Blobel 2001). Finally, HrpF may affect effector activity in some unknown manner, which facilitates effector uptake. In any event, $X$. oryzae pv. oryzae hrpF mutants also were unable to trigger $B s 3$-dependent reactions in pepper plants. If $X$. oryzae pv. oryzae and $X$. campestris pv. vesicatoria are assumed to deliver the effectors with equal efficiencies, differences may exist in the sensitivity of the AvrB3/Bs3 interaction or ability of rice and pepper cells to take up the effectors.

\section{MATERIALS AND METHODS}

\section{Bacterial strains and plasmids.}

The bacterial strains and plasmids used in the experiments are listed in Table 1. Escherichia coli strains were grown in terrific broth or on Luria agar plates at $37^{\circ} \mathrm{C}$ with the appropriate antibiotics. Xanthomonas strains were cultured on tryptone sucrose agar at $28^{\circ} \mathrm{C}$ (Zhu et al. 2000). The genomic library of

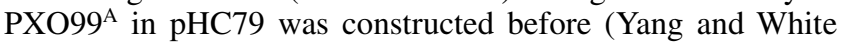
2004). Carbenicillin, spectinomycin, gentamicin, and kanamycin were used at $100 \mu \mathrm{g} / \mathrm{ml}$.

\section{Recombinant DNA techniques.}

DNA manipulations were performed by standard procedures (Sambrook et al. 1987). Ligase, SuperScript II reverse transcriptase, and Accuprime Taq DNA polymerase were purchased from Invitrogen (Carlsbad, CA, U.S.A.). An EZ::TN <KAN$2>$ insertion kit (Epicentre Technologies, Madison, WI, U.S.A.) was used for random insertion of transposon into plasmids and cosmids. Radio-labeled dCTP was purchased from PerkinElmer (Wellesley, MA, U.S.A.). Hybond N+ (Amersham Pharmacia Biotech, Piscataway, NJ, U.S.A.) was used for Northern blot hybridization. Rediprime II random prime labeling system and Microspin (Amersham Pharmacia Biotech) were used to prepare probes for Northern blot hybridization. Each kit was used according to the manufacturer's instructions. Sequencing was performed at Kansas State University Sequencing Facilities. Amino acid alignments were constructed using ClustalW (Thompson et al. 1994). Identity and similarity comparisons were calculated using NTI Vector software (Infomax, Bethesda, MD, U.S.A.).

\section{DNA amplification.}

The primer sequences used in this study are provided in Table 2. The primers KohrpFxoF and KohrpFxoR were used to amplify a partial fragment of $h r p F$ by polymerase chain reaction (PCR) from genomic DNA. The complete $h r p F$ gene was amplified from cosmid clone pAS49 using Fshort1 and Rshort1. The hpaF gene was amplified from pAS49 by PCR using hpaFF1 and hpaFR1. The hpa3-hpa4 locus was amplified by PCR using hpa34F and hpa34R. hrpF genes from $X$. campestris pv. campestris, $X$. axonopodis pv. citri, and $X$. campestris pv. vesicatoria were amplified from the respective genomic DNA by PCR using the following sets of primers: hrpFxcc, XcchrpFf, and XcchrpFr; hrpFxac, XachrpFf, and XachrpFr; and hrpFxcv, XcvhrpFf, and XcvhrpFr, respectively. The hpal gene was amplified from $X$. oryzae pv. oryzae genomic DNA using hpa1-BamHI2 and hpa1-KpnI2. Gentamicin 3-acetyltransferase gene was PCR amplified from 
pKockoutG (Windgassen et al. 2000) using the primers GmFEco and GmR-Eco. The 3' untranslated region of TFIIA $\gamma 1$ was amplified from rice IRBB7 genomic DNA by PCR using Chr1TF2F and Chr1TF2R. The parameters used for PCR were as follows: step $1,95^{\circ} \mathrm{C}$ for $2 \mathrm{~min}$; step $2,95^{\circ} \mathrm{C}$ for $30 \mathrm{~s}$; step $3,50^{\circ} \mathrm{C}$ for $30 \mathrm{~s}$; step $4,68^{\circ} \mathrm{C}$ for $1 \mathrm{~min}$ per kilobase; 25 cycles from step 2 to step 4 ; and step5, $68^{\circ} \mathrm{C}$ for $5 \mathrm{~min}$.

\section{Transposon and deletion mutagenesis.}

The hrpF mutant ASX41 was constructed by a single homologous recombination using $654 \mathrm{bp}$ of $h r p F$, which was amplified by PCR. The fragment was cloned in pCR2.1TOPO, which carries genes for resistance to kanamycin and carbenicillin, and the plasmid was designated as pAS18. pAS18 was introduced into $X$. oryzae pv. oryzae strain PXO99 ${ }^{\mathrm{A}}$ by single homologous recombination. The recombinants were screened by resistance to kanamycin. For the complementation, the complete $h r p F$ gene, including approximately $500 \mathrm{bp}$ upstream from the start codon, was amplified from pAS49 and was cloned into pCR2.1-TOPO. The plasmid was termed pAS50 and sequenced. pAS50 was ligated with broad-host-range vector pHM1 at the unique KpnI site, resulting in pAS65. To construct hrpF mutant ASX85, a NotI and HindIII fragment was excised from pAS50 and cloned into pBluescript II KS(+) and termed pAS61. Transposons were inserted randomly into pAS61 using an EZ::TN <KAN-2> insertion kit according to the directions of the manufacturer (Epicentre Technologies), and a plasmid with a transposon insertion in the $h r p F$ coding sequence at $507 \mathrm{bp}$ from the start codon was selected for further use. The plasmid was designated as pAS64. pAS64 was introduced into PXO99 ${ }^{\mathrm{A}}$, and a double recombinant clone, called ASX85, was selected on the basis of resistance to kanamycin resistance (retention of insertion) and sensitivity to carbenicillin (loss of vector sequences). The recombination event was verified by PCR amplification and sequencing of a fragment containing one end of the transposon sequence and flanking genomic sequence. To generate a mutation in $h p a F$ mutants, a $2.4-\mathrm{kb}$ fragment containing a portion of $h p a F$ was obtained by PCR and double digestion with $X b a I$ and $S a c I$. The fragment was ligated in pBluescript II $\mathrm{KS}(+)$, and the clone was subjected to mutagenesis with EZ::TN $<$ KAN-2 $>$ transposons. A plasmid with an insertion at 419 bp from the $h p a F$ start codon was selected for use. The plasmid was introduced into $\mathrm{PXO}^{\mathrm{A}}$ and recombinants from a double recombination event were selected on the basis of resistance to kanamycin and sensitivity to carbenicillin. The mutation in $h p a F$ was verified by PCR and sequence analysis of genomic DNA. To obtain hpa3 and hpa4 mutants, the hpa3 and hpa4 region was amplified by PCR and cloned into pGEM-T Easy Vector. The resulting plasmid was subjected to mutagenesis with EZ::TN $<\mathrm{KAN}-2>$ transposons. Plasmids with insertions at $447 \mathrm{bp}$ from the hpa3 start codon or 1,140 bp from

Table 2. Primer sequences

\begin{tabular}{|c|c|}
\hline Primer name & Sequence \\
\hline KohrpFxoF & $5^{\prime}$-acctgccatcgacgatggatac-3' \\
\hline KohrpFxoR & $5^{\prime}$-cagctcaatcaatccgaactgg-3' \\
\hline Fshort1 & $5^{\prime}$-attaatgaggtattcactatctgcgc- $3^{\prime}$ \\
\hline Rshort1 & $5^{\prime}$-gcgcgttatctgcgacgtatcctg-3' \\
\hline hpaFF1 & $5^{\prime}$-atcgcttgecgacgttcgtatg- $3^{\prime}$ \\
\hline hpaFR1 & $5^{\prime}$-cgcttggcgaagtagctcgec- $3^{\prime}$ \\
\hline hpa34F & $5^{\prime}$-ccaacggattcgtatttagtaacac- $3^{\prime}$ \\
\hline hpa34R & $5^{\prime}$-tcatgctcgecegctttgccac- $3^{\prime}$ \\
\hline XcchrpFf & $5^{\prime}$-cctgatcaacacagttgctccac- $3^{\prime}$ \\
\hline XcchrpFr & $5^{\prime}$-gtcgctcaagcaagatcgttacttg-3' \\
\hline XachrpFf & $5^{\prime}$-gagcgaccttgatccggtgaatcatc- $3^{\prime}$ \\
\hline XachrpFr & $5^{\prime}$-ctaacgcaaatgtcgctgtggcatg- $3^{\prime}$ \\
\hline XcvhrpFf & $5^{\prime}$-cagcaaatccagggctgcagtcag- $3^{\prime}$ \\
\hline XcvhrpFr & $5^{\prime}$-cttcgctgtggcatgcgegttatc $-3^{\prime}$ \\
\hline hpa1-BamHI2 & $5^{\prime}$-atcgeggatcceggetgcatcaacgcttccttggag- $3^{\prime}$ \\
\hline hpa1-KpnI2 & $5^{\prime}$-gacccggggtaccttgagtcaccgectggatgatc- $3^{\prime}$ \\
\hline GmF-Eco & $5^{\prime}$-atcacagaattcgaggacgcgtcaattctcgaattg- $3^{\prime}$ \\
\hline GmR-Eco & $5^{\prime}$-tacaatgaattcctcgaattgacgcgtcgccgggaag-3' \\
\hline Chr1TF2F & $5^{\prime}$-gctggagactaaagaagagtaattgc- $3^{\prime}$ \\
\hline Chr1TF2R & $5^{\prime}$-gagcacactcatgtcacacatcac- $3^{\prime}$ \\
\hline
\end{tabular}

Table 1. Strains and plasmids used in the study

\begin{tabular}{|c|c|c|}
\hline Strain & Relevant characteristics $^{\mathbf{a}}$ & Source \\
\hline \multicolumn{3}{|l|}{ Xanthomonas oryzae pv. oryzae } \\
\hline PXO99 & 5-azacytidine resistant, race 6 & Hopkins et al. 1992 \\
\hline PXO99AME7 & hrpC mutant, $\mathrm{Km}^{\mathrm{r}}$ & Zhu et al. 2000 \\
\hline ASX41 & PXO99 ${ }^{\mathrm{A}} h r F^{-}$, single recombinant of pAS $18, \mathrm{Km}^{\mathrm{r}}$ & This study \\
\hline ASX85 & PXO99 ${ }^{\mathrm{A}} h r p F^{-}$, double recombinant of pAS64, $\mathrm{Km}^{\mathrm{r}}$ & This study \\
\hline ASX153 & $\mathrm{PXO}^{\mathrm{A}}$ hrpF $^{-}$hpal $^{-}$, double recombinant of pAS127, $\mathrm{Km}^{\mathrm{r}} \mathrm{Gn}^{\mathrm{r}}$ & This study \\
\hline ASX155 & PXO99 ${ }^{\mathrm{A}}$ hpal $^{-}$, double recombinant of pAS127, $\mathrm{Gn}^{\mathrm{r}}$ & This study \\
\hline X. campestris pv. vesicatoria & Strain XV157 & Gift from J. Jones \\
\hline$X$. campestris pv. campestris & Strain ATCC33913 & \\
\hline$X$. axonopodis pv. citri & Strain 306 & \\
\hline \multicolumn{3}{|l|}{ Plasmids } \\
\hline pBluescript II KS(+) & Phagemid, pUC derivative, $\mathrm{Cb}^{\mathrm{r}}$ & Stratagene \\
\hline pCR2.1-TOPO & Phagemid, $\mathrm{Cb}^{\mathrm{r}}, \mathrm{Km}^{\mathrm{r}}$ & Invitrogen \\
\hline pHM1 & Broad-host-range vector with pUC19 polylinker, $\mathrm{Sp}^{\mathrm{r}}$ & Hopkins et al. 1992 \\
\hline pAS18 & pCR2.1-TOPO with partial hrpFxoo2 & This study \\
\hline pAS49 & Cosmid (pHC79) clone of hrpFxoo2 region & This study \\
\hline pAS50 & pCR2.1-TOPO with hrpFxoo2 & This study \\
\hline pAS61 & pBluescript II KS(+) with hrpFxoo2 & This study \\
\hline pAS64 & pAS61 with transposon inserted in hrpFxoo2 & This study \\
\hline pAS65 & pAS50 ligated with pHM1 & This study \\
\hline pZWavrXa10 & avrXa10 fused to lacZ promoter of pBluescript II KS(+) & Yang et al. 2000 \\
\hline pZWavrXa7 & $a v r X a 7$ fused to lacZ promoter of pBluescript II KS(+) & Yang et al. 2000 \\
\hline pAS127 & hpal with gentamicin 3-acetyltransferase $\left(\mathrm{Gn}^{\mathrm{r}}\right)$ insertion & This study \\
\hline pAS76 & pHM1 with $h r p F x c v$ & This study \\
\hline pAS74 & pHM1 with $h r p F x a c$ & This study \\
\hline pAS109 & pHM1 with hrpFxcc & This study \\
\hline pHM1::avrBs1-2 & pHM1 with avrBs 1 ORF1 and 2 & X. Tang, unpublished \\
\hline pHM1::avrBs3 & pHM1 with $a v r B s 3$ & Zhu et al. 1998 \\
\hline
\end{tabular}

${ }^{\mathrm{a}} \mathrm{Km}=$ kanamycin, $\mathrm{Gn}=$ gentamicin, $\mathrm{Cb}=$ carbenicillin, $\mathrm{Sp}=$ spectinomycin, and $\mathrm{ORF}=$ open reading frame. 
hpa4 start codon were isolated and introduced into PXO99 ${ }^{\mathrm{A}}$. Mutants generated by double recombination event were selected as described above for hrpFxoo.

A 1.8-kb DNA fragment containing hpal was amplified by PCR, digested by BamHI and KpnI, and ligated with pBluescript II KS(+) to construct an hpal hrpF double mutant. The gene for gentamicin-3-acetyltransferase, which was amplified by PCR using the primers with EcoRI sites, was inserted into the EcoRI site of hpal. The plasmid was termed pAS127 and was introduced into the $h r p F$ mutant ASX85 by electroporation and selection for resistance to gentamicin. hrpA single mutant ASX155 was similarly generated by introducing pAS127 into the wild-type strain PXO99 ${ }^{\mathrm{A}}$. Recombinants due to double homologous recombination were identified on the basis of sensitivity to carbenicillin and verified by PCR analysis.

The $h r p F$ genes and their respective promoter regions were amplified by PCR from genomic DNA from $X$. campestris $\mathrm{pv}$. campestris, $X$. axonopodis pv. citri, and $X$. campestris pv. vesicatoria and each gene was cloned into pCR2.1. Each gene is designated by a three-letter code subscript, which refers to the species of origin, as follows: $X$ axonopodis pv. citri (xac), $X$. axonopodis pv. glycine (xag), X. campestris pv. campestris (xcc), X. campestris pv. vesicatoria $(\mathrm{xcv})$, and $X$. oryzae $\mathrm{pv}$. oryzae (xоo). The resulting plasmids then were digested by HindIII ( $X$. campestris pv. vesicatoria and $X$. campestris pv. campestris) or SacI ( $X$ axonopodis pv. citri) and ligated with pHM1, and the plasmids were termed pAS76, 74, and 109, respectively.

\section{Plant assays.}

Pathogenicity and hypersensitivity assays were performed as previously described (Hopkins et al. 1992). Tomato cv. VFN-8; pepper cvs. ECW, 10R, and 30R; cabbage cv. Goldenacre; and grapefruit cv. Duncan (Citrus paradisii) were used as hosts for hypersensitivity tests of the respective strains. Nine-day-old rice seedlings IRBB10 and IRBB7, containing corresponding resistance genes $\mathrm{Xa10}$ and $\mathrm{Xa7}$, respectively, were used for race-specific resistance assays of $X$. oryzae pv. oryzae. Seedlings of IR24 (21 days old) were used for pathogenicity tests in rice. All plants were grown in growth chambers at $28^{\circ} \mathrm{C}$ with a 12 -h photoperiod. Inoculum concentrations were adjusted to an optical density of 0.5 at $600 \mathrm{~nm}$ (approximately $0.5 \times 10^{8}$ $\mathrm{CFU} / \mathrm{ml}$ ) using a DU640B spectrophotometer (Beckman Coulter, Fullerton, CA, U.S.A.). For hypersensitivity tests, plants were inoculated by needleless syringe infiltration (Zhu et al. 1998). Symptoms were scored by measuring lesion length after the leaf clip inoculation (Kauffman et al. 1973). Scores are the mean of three leaves. Bacterial growth in rice leaves was measured by harvesting three leaves $(20 \mathrm{~cm})$ for each treatment after leaf clip inoculation. The leaves were ground with a mortar and pestle in $5 \mathrm{ml}$ of sterile water. The solution was diluted serially and spread on TSA plates with either kanamycin (for PXO99 ${ }^{\mathrm{A}} \mathrm{ME} 7$ ) or spectinomycin, depending on the genotype of the strain. The mean number of colonies in three plates of the proper dilution (10 to 100 colonies) was calculated. Significance between treatments was assessed using log-converted data on the basis of a $P$ value $<0.05$, using the Tukey test for post analysis of variance.

\section{Northern hybridization analysis.}

The second leaf of 14-day-old rice plants was inoculated at multiple sites with bacterial suspensions prepared as described above or by sterile water with a needleless syringe. The leaves were harvested 12 and $24 \mathrm{~h}$ after inoculation to detect the induction of POX22.3 and TFIIA $\gamma 1$, respectively. Total RNA was extracted by using Trizol following the instructions of the manufacture (Invitrogen). Approximately $15 \mu \mathrm{g}$ of total RNA was loaded for each sample and subjected to electrophoresis in $1 \%$ agarose gels. The RNA was transferred to Hybond N+ (Amersham Biosciences). The membrane was hybridized with a specific probe at $65^{\circ} \mathrm{C}$ in hybridization buffer $(5 \times \mathrm{SSC}[1 \times$ SSC is $0.15 \mathrm{M} \mathrm{NaCl}$ plus $0.015 \mathrm{M}$ sodium citrate], $0.5 \%$ sodium dodecyl sulfate, $20 \mathrm{mM} \mathrm{Na} \mathrm{HPO}_{4} / \mathrm{NaH}_{2} \mathrm{PO}_{4}$ [pH 6.5], 5 $\mathrm{mM}$ EDTA, and $1 \mathrm{mM}$ Tris- $\mathrm{HCl})$. The probe for the peroxidase gene POX22.3 (NCBI accession AF014467) was amplified from the unique $3^{\prime}$ untranslated region by PCR as described previously (Chittoor et al. 1997). The 3' untranslated region of TFIIA $\gamma 1$ was amplified by PCR and used as a probe.

\section{ACKNOWLEDGMENTS}

This study was supported by funds from the Tillman Scholarship Fund (A. Sugio), USDA-CREES-NRI (F. F. White), and the Kansas Agriculture Experiment Station (publication 05-172-J). We thank J. Jones for providing $X$. campestris pv. vesicatoria XV157 and grapefruit plants (Citrus paradisii var. Duncan), X. Tang for providing pHM1::avrBs1-2 and pepper plant ECW 10R, A. Bogdanov for providing pepper ECW 30R and helping bacterium inoculation, and M. Leathers for technical assistance.

\section{LITERATURE CITED}

Alfano, J. R., Charkowski, A. O., Deng, W. L., Badel, J. L., PetnickiOcwieja, T., van Dijk, K., and Collmer, A. 2000. The Pseudomonas syringae Hrp pathogenicity island has a tripartite mosaic structure composed of a cluster of type III secretion genes bounded by exchangeable effector and conserved effector loci that contribute to parasitic fitness and pathogenicity in plants. Proc. Natl. Acad. Sci. U.S.A. 97:4856-4861.

Bellato, C., Krishnan, H. B., Cubo, T., Temprano, F., and Pueppke, S. G. 1997. The soybean cultivar specificity gene nolX is present, expressed in a nodD-dependent manner, and of symbiotic significance in cultivarnonspecific strains of Rhizobium (Sinorhizobium) fredii. Microbiology 143(Pt 4):1381-1388.

Broms, J. E., Sundin, C., Francis M. S., and Forsberg, A. 2003. Comparative analysis of type III effector translocation by Yersinia pseudotuberculosis expressing native LcrV or PcrV from Pseudomonas aeruginosa. J. Infect. Dis. 188:239-249.

Brown, I. R., Mansfield, J. W., Taira, S., Roine, E., and Romantschuk, M. 2001. Immunocytochemical localization of HrpA and HrpZ supports a role for the Hrp pilus in the transfer of effector proteins from Pseudomonas syringae pv. tomato across the host plant cell wall. Mol. PlantMicrobe Interact. 14:394-404.

Buttner, D., and Bonas, U. 2002a. Getting across-bacterial type III effector proteins on their way to the plant cell. EMBO (Eur. Mol. Biol. Organ.) J. 21:5313-5322.

Buttner, D., and Bonas, U. 2002b. Port of entry-the type III secretion translocon. Trends Microbiol. 10:186-192.

Buttner, D., Nennstiel, D., Klusener, B., and Bonas, U. 2002. Functional analysis of HrpF, a putative type I II translocon protein from Xanthomonas campestris pv. vesicatoria. J. Bacteriol. 184:2389-2398.

Charkowski, A. O., Alfano, J. R., Preston, G., Yuan, J., He, S. Y., and Collmer, A. 1998. The Pseudomonas syringae pv. tomato HrpW protein has domains similar to harpins and pectate lyases and can elicit the plant hypersensitive response and bind to pectate. J. Bacteriol. 180:5211-5217.

Chittoor, J. M., Leach, J. E., and White, F. F. 1997. Differential induction of a peroxidase gene family during infection of rice by Xanthomonas oryzae pv. oryzae. Mol. Plant-Microbe Interact. 10:861-871.

da Silva, A. C., Ferro, J. A., Reinach, F. C., Farah, C. S., Furlan, L. R., Quaggio, R. B., Monteiro-Vitorello, C. B., Van Sluys, M. A., Almeida, N. F., Alves, L. M., do Amaral, A. M., Bertolini, M. C., Camargo, L. E., Camarotte, G., Cannavan, F., Cardozo, J., Chambergo, F., Ciapina, L. P., Cicarelli, R. M., Coutinho, L. L., Cursino-Santos, J. R., El-Dorry, H., Faria, J. B., Ferreira, A. J., Ferreira, R. C., Ferro, M. I., Formighieri, E. F., Franco, M. C., Greggio, C. C., Gruber, A., Katsuyama, A. M., Kishi, L. T., Leite, R. P., Lemos, E. G., Lemos, M. V., Locali, E. C., Machado, M. A., Madeira, A. M., Martinez-Rossi, N. M., Martins, E. C., Meidanis, J., Menck, C. F., Miyaki, C. Y., Moon, D. H., Moreira, L. M., Novo, M. T., Okura, V. K., Oliveira, M. C., Oliveira, V. R., Pereira, H. A., Rossi, A., Sena, J. A., Silva, C., de Souza, R. F., Spinola, L. A., Takita, M. A., Tamura, R. E., Teixeira, E. C., Tezza, R. I., Trindade dos Santos, M., Truffi, D., Tsai, S. M., White, F. F., Setubal, J. C. and Kitajima, J. P. 2002. Comparison of the genomes of two Xanthomonas pathogens with differing host specificities. Nature 417:459-463. 
Goel, A. K., Rajagopal, L., Nagesh, N., and Sonti, R. V. 2002. Genetic locus encoding functions involved in biosynthesis and outer membrane localization of xanthomonadin in Xanthomonas oryzae pv. oryzae. J. Bacteriol. 184:3539-3548.

Hacker, J., and Kaper, J. B. 2000. Pathogenicity islands and the evolution of microbes. Annu. Rev. Microbiol. 54:641-679.

Hoiczyk, E., and Blobel, G. 2001. Polymerization of a single protein of the pathogen Yersinia enterocolitica into needles punctures eukaryotic cells. Proc. Natl. Acad. Sci. U.S.A. 98:4669-4674.

Holmstrom, A., Olsson, J., Cherepanov, P., Maier, E., Nordfelth, R., Pettersson, J., Benz, R., Wolf-Watz, H., and Forsberg, A. 2001. LcrV is a channel size-determining component of the Yop effector translocon of Yersinia. Mol. Microbiol. 39:620-632.

Hopkins, C. M., White, F. F., Choi, S. H., Guo, A., and Leach, J. E. 1992 Identification of a family of avirulence genes from Xanthomonas oryzae pv. oryzae. Mol. Plant-Microbe Interact. 5:451-459.

Horn, M. A., Heinstein, P. F., and Low, P. S. 1989. Receptor-mediated endocytosis in plant cells. Plant Cell 1:1003-1009.

Huguet, E., and Bonas, U. 1997. hrpF of Xanthomonas campestris pv. vesicatoria encodes an $87-\mathrm{kDa}$ protein with homology to NoIX of Rhizobium fredii. Mol. Plant-Microbe Interact. 10:488-498.

Kauffman, H. E., Reddy, A. P. K., Hsiek, S. P. V., and Marca, S. D. 1973. An improved technique for evaluating resistance of race varieties to Xanthomonas oryzae. Plant Dis. Rep. 57:537-541.

Kim, J. F., and Beer, S. V. 1998. HrpW of Erwinia amylovora, a new harpin that contains a domain homologous to pectate lyases of a distinct class. J. Bacteriol. 180:5203-5210.

Kim, J. G., Park, B. K., Yoo, C. H., Jeon, E., Oh, J., and Hwang, I. 2003. Characterization of the Xanthomonas axonopodis pv. glycines Hrp pathogenicity island. J. Bacteriol. 185:3155-3166.

Krishnan, H. B. 2002. NolX of Sinorhizobium fredii USDA257, a type IIIsecreted protein involved in host range determination, is localized in the infection threads of cowpea (Vigna unguiculata (L.) Walp.) and soybean (Glycine $\max$ (L.) Merr.) nodules. J. Bacteriol. 184:831-839.

Lee, J., Klusener, B., Tsiamis, G., Stevens, C., Neyt, C., Tampakaki, A. P., Panopoulos, N. J., Noller, J., Weiler, E. W., Cornelis, G. R., Mansfield, J. W., and Nurnberger, T. 2001. HrpZ(Psph) from the plant pathogen Pseudomonas syringae pv. phaseolicola binds to lipid bilayers and forms an ion-conducting pore in vitro. Proc. Natl. Acad. Sci. U.S.A. 98:289-294.

Lindgren, P. B., Peet, R. C., and Panopoulos, N. J. 1986. Gene cluster of Pseudomonas syringae pv. phaseolicola controls pathogenicity on bean plants and hypersensitivity on nonhost plants. J. Bacteriol. 168:512522

Meinhardt, L. W., Krishnan, H. B., Balatti, P. A., and Pueppke, S. G. 1993. Molecular cloning and characterization of a sym plasmid locus that regulates cultivar-specific nodulation of soybean by Rhizobium fredii USDA257. Mol. Microbiol. 9:17-29.

Neyt, C., and Cornelis, G. R. 1999. Insertion of a Yop translocation pore into the macrophage plasma membrane by Yersinia enterocolitica: Requirement for translocators YopB and YopD, but not LcrG. Mol. Microbiol. 33:971-981.
Noel, L., Thieme, F., Nennstiel, D., and Bonas, U. 2002. Two novel type III-secreted proteins of Xanthomonas campestris pv. vesicatoria are en coded within the hrp pathogenicity island. J. Bacteriol. 184:1340-1348.

Petnicki-Ocwieja T, van Dijk, K., and Alfano, J. R. 2005. The hrpK operon of Pseudomonas syringae pv. tomato DC3000 encodes two proteins secreted by the type III (Hrp) protein secretion system: HopB1 and HrpK, a putative type III translocator. J. Bacteriol. 187:649-663.

Roden, J. A., Belt, B., Ross, J. B., Tachibana, T., Vargas, J., and Mudgett M. B. 2004. A genetic screen to isolate type III effectors translocated into pepper cells during Xanthomonas infection. Proc. Natl. Acad. Sci. U.S.A. 101:16624-16629.

Roine, E., Wei, W., Yuan, J., Nurmiaho-Lassila, E. L., Kalkkinen, N., Romantschuk, M., and He, S. Y. 1997. Hrp pilus: An hrp-dependent bacterial surface appendage produced by Pseudomonas syringae pv. tomato DC3000. Proc. Natl. Acad. Sci. U.S.A. 94:3459-3464.

Rossier, O., Van den Ackerveken, G., and Bonas, U. 2000. HrpB2 and HrpF from Xanthomonas are type III-secreted proteins and essential for pathogenicity and recognition by the host plant. Mol. Microbiol. 38:828-838.

Salanoubat, M., Genin, S., Artiguenave, F., Gouzy, J., Mangenot, S., Arlat, M., Billault, A., Brottier, P., Camus, J. C., Cattolico, L., Chandler, M., Choisne, N., Claudel-Renard, C., Cunnac, S., Demange, N., Gaspin, C., Lavie, M., Moisan, A., Robert, C., Saurin, W., Schiex, T., Siguier, P. Thebault, P., Whalen, M., Wincker, P., Levy, M., Weissenbach, J., and Boucher, C. A. 2002. Genome sequence of the plant pathogen Ralstonia solanacearum. Nature 415:497-502.

Sambrook, J., Fritsch, E. F., and Maniatis, T. 1987. Molecular Cloning: A Laboratory Manual. Cold Spring Harbor Laboratory Press, Cold Spring Harbor, NY, U.S.A.

Thompson, J. D., Higgins, D. G., and Gibson, T. J. 1994. CLUSTAL W: Improving the sensitivity of progressive multiple sequence alignment through sequence weighting, position-specific gap penalties and weight matrix choice. Nucleic Acids Res. 22:4673-4680.

Windgassen, M., Urban, A., and Jaeger, K. E. 2000. Rapid gene inactivation in Pseudomonas aeruginosa. FEMS (Fed. Eur. Microbiol. Soc.) Microbiol. Lett. 193:201-205.

Yang, B., and White, F. F. 2004. Diverse members of the AvrBs3/PthA family of type III effectors are major virulence determinants in bacterial blight disease of rice. Mol. Plant-Microbe Interact. 17:1192-1200.

Yang, B., Zhu, W., Johnson, L. B., and White, F. F. 2000. The virulence factor AvrXa7 of Xanthomonas oryzae pv. oryzae is a type III secretion pathway-dependent nuclear-localized double-stranded DNA-binding protein. Proc. Natl. Acad. Sci. U.S.A. 97:9807-9812.

Zhu, W., Magbanua, M. M., and White, F. F. 2000. Identification of two novel hrp-associated genes in the hrp gene cluster of Xanthomonas oryzae pv. oryzae. J. Bacteriol. 182:1844-1853.

Zhu, W., Yang, B., Chittoor, J. M., Johnson, L. B., and White, F. F. 1998 AvrXa10 contains an acidic transcriptional activation domain in the functionally conserved $\mathrm{C}$ terminus. Mol. Plant-Microbe Interact. 11:824-832. 